Биомедиичинская химия, 2013 том 59, вып. 3, с. 349-357.

УДК 577.336

СВекшин

\title{
ФОТО-АКТИВНОСТЬ АКТИНОМИЦИНОВ
}

\section{Н.Л. Векшин}

ФГБУН Институт биофизики клетки РАН, г. Пущино, 142290, Московская область; эл. почта: nvekshin@rambler.ru

На примере актиномицинов изучена возможность повышения противоопухолевой активности гетероциклических антибиотиков за счёт фото-активации. В модельных опытах с растворами актиномицинов показано, что они обладают собственной фотохимической активностью, заметно изменяющейся при связывании с ДНК в растворе или в опухолевых клетках. Обнаружена быстрая фотодеструкция клеток HeLa и высвобождение из них антибиотика.

Ключевые слова: противоопухолевые антибиотики, актиномицин, 7-аминоактиномицин, флуоресценция, клетки HeLa, фотодеструкция, кофеин.

ВВЕДЕНИЕ. Природные гетероциклические антибиотики давно используются для лечения ряда опухолевых заболеваний [1]. Применение многих из них основано на способности формировать специфический устойчивый комплекс с ядерной ДНК и ингибировать этим РНК-полимеразную реакцию, в результате чего подавляются синтез белка и клеточное деление $[1,2]$.

Некоторые гетероциклические антибиотики при низких концентрациях образуют прочные нестэкинговые комплексы с расплетенными участками ДНК, тем самым стабилизируя молекулу ДНК. Вероятно, именно поэтому они проявляют противоопухолевую активность (в отличие от стэкинговых красителей-интеркаляторов типа бромида этидия - сильнейшего канцерогена). Типичными среди них являются актиномицины [1].

Большинство гетероциклических антибиотиков плохо проникают внутрь клеток. Имеются сведения о транспортировке антибиотиков в клетки с помощью липосом [1]. Проникновение антибиотиков, например актиномицинов, в опухолевые клетки можно усилить путём нагрева, а также с помощью формирования специальных комплексов антибиотика со шпилечными олигонуклеотидами [2].

Как будет показано в данной работе на примере природного антибиотика актиномицина Д (АМД) и его флуоресцирующего аналога 7-амино-актиномицина Д (7ААМД), их накопление в модельных опухолевых клетках $\mathrm{HeLa}$ и последующее интенсивное световое облучение вызывает быстрое повреждение и даже деструкцию этих клеток. 
МЕТОДИКА.

Pеактивы. В работе использовали: актиномицин Д и 7-аминоактиномицин Д (“Reanal”, Венгрия и "Fluka”, Швейцария), ДНК из фага лямбда (No 25250-010 "GibcoBRL", США), а также кофеин отечественного производства (хч). Все растворы готовили на бидистиллированой воде непосредственно в день опыта. Концентрацию АМД и 7ААМД определяли фотометрически, исходя из коэффициента экстинкции.

Спектроскопия. Спектры поглощения АМД и 7ААМД регистрировали в диапазоне 220-600 нм на спектрофотометре "Specord M-40" (“Carl Zeiss", Германия) в кюветах с оптическим путём от 0,1 см до 1 см. Коэффициенты экстинкции АМД и 7ААМД при 440 нм и 540 нм брались равными $24500 \mathrm{M}^{-1} \cdot \mathrm{cm}^{-1}$ и $24000 \mathrm{M}^{-1} \cdot \mathrm{cm}^{-1}$, соответственно [1]. Спектры флуоресценции 7ААМД регистрировали в диапазоне 560-790 нм (длина волны возбуждения 530 нм) на спектрофлуориметре "Perkin-Elmer MPF-44B" или "SLM-4800" (США) в 1-см кварцевых кюветах при $20^{\circ} \mathrm{C}$.

Проникновение антибиотика в клетки HeLa. Исследование проникновения АМД и 7ААМД, использованных в микромолярных концентрациях, в опухолевые клетки проводили в “мягких" условиях (инкубация 5 мин при $20^{\circ} \mathrm{C}$ ) и “жёстких" условиях (инкубация 30 мин при $37^{\circ} \mathrm{C}$ ). Использовали модельные опухолевые клетки HeLa (из лаборатории клеточной инженерии ИТЭБ РАН), культивированные на питательной среде RPMI 1640. В ходе опытов средой для работы с клетками служил 20 мМ трис буфер с 200 мМ сахарозой $(\mathrm{pH}=7,5)$. После инкубации с антибиотиком образцы центрифугировали в течение 5 мин при $1000 \mathrm{~g}$ для осаждения клеток (в клетках оставался только связавшийся с клетками 7ААМД или АМД). После этого супернатант отбирали и отбрасывали, а осадок клеток разбавляли до нужной концентрации.

Фотоактиващия. Облучение 7ААМД в растворе производили с помощью 450-вт ксеноновой лампы. Свет проходил через тепловой фильтр (5\% раствор сернокислой меди), интерференционный светофильтр 540 нм и нейтральный ослабляющий светофильтр НС-3, после чего попадал на 200 мкл раствора образца, помещённого в герметично закрытую 0,4-см зеркальную микрокювету, которая усиливает флуоресцентный сигнал, а также ускоряет фотохимические реакции. При этом световой пучок охватывал весь объём раствора. Нагрев раствора в ходе облучения не превышал 1 градуса. Эксперименты по фотоактивации АМД в растворе и клетках проводили с помощью той же лампы. При этом образцы, термостатируемые при $20^{\circ} \mathrm{C}$, помещали в 1-см зеркальные кюветы и освещали через тепловой фильтр (без светофильтров). Аналогичным образом осуществлялось облучение антибиотика, накопившегося в клетках при инкубации.

Микроскопия. Микрофотографии клеток HeLa были получены с помощью оптического микроскопа Carl Zeiss и цифровой фотокамеры Sony Cyber Shot, 5 Мегапикселей (“Sony”, Корея).

\section{РЕЗУЛЬТАТЫ И ОБСУЖДЕНИЕ.}

Проникновение. Проникновение АМД и 7ААМД в опухолевые клетки линии HeLa исследовали в мягких условиях (инкубация 5 мин при $20^{\circ} \mathrm{C}$ ) и жёстких условиях (инкубация 30 мин при $37^{\circ} \mathrm{C}$ ).

Как оказалось, при мягких условиях инкубации АМД и 7ААМД в микромолярных концентрациях плохо проникают в клетки HeLa. Однако, в жёстких условиях наблюдалось хорошее проникновение. В таблице 1 приведены данные по проникновению 7ААМД из внешнего раствора внутрь клеток. Чётко видно, что исходно в растворе антибиотик есть, а после инкубации - практически нет. Он почти весь входит в клетки. 
При этом нужно отметить исходную неаддитивность интенсивности его флуоресценции и фоновой интенсивности самих клеток. Это говорит о том, что внутри клеток 7ААМД излучает гораздо слабее, чем во внешнем растворе. Последнее позволяет предположить, что он, входя в клетки, хуже поглощает возбуждающий свет, и/или он чем-то в клетках сильно дезактивируется (тушится). Однако после завершения инкубации, когда в клетках накапливается довольно много антибиотика, он начинает флуоресцировать очень интенсивно - почти на порядок сильней, чем в растворе.

Таблица 1. Интенсивность флуоресценции 7-амино-актиномицина Д в клетках HeLa.

\begin{tabular}{|c|c|}
\hline Нсходно: & Интенсинность фууоресценция (онед) \\
\hline 7AAMД в pacizope & $1 \pm 0,01$ \\
\hline Krets. с 7AAMJ & $1,24 \pm 0,03$ \\
\hline Kmenkn 6es a múnomika & $1,04 \pm 0,02$ \\
\hline Поспе инкубарцак & (30 พ19н III 37' \\
\hline OcraTos 7AAMД в pacmope & $0,04 \pm 0,02$ \\
\hline 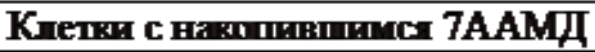 & $8 \pm 0,06$ \\
\hline Kmenkn 6es a ank6romika & $2,64 \pm 0,05$ \\
\hline
\end{tabular}

Примечание: Образцы флуориметрировались в зеркальных микрокюветах.

Возбуждение - 540 нм, эмиссия - 610 нм. Концентрация 7-ААМД - 10 мкМ. Здесь и в таблицах 2-4 приведены средние значения \pm ошибка средней из десяти независимых опытов.

Обнаружено, что при проникновении актиномицинов внутрь клеток они способны уменьшать триптофановую флуоресценцию клеточных белков. Данные для АМД показаны в таблице 2. Для исключения экранирования (при 295 нм) и реабсорбции (при 338 нм) триптофановой флуоресценции внешними молекулами АМД раствора измерения были проведены на инкубированных с антибиотиком в течение 30 мин клетках с последующим их повторным переосаждением (с накопившимся внутри них антибиотиком). При этом, однако, нельзя исключить возможность микро-экранировки возбуждающего света (при 295 нм) и микро-реабсорбции (при 338 нм) триптофановой флуоресценции молекулами АМД, скопившимися внутри клеток. Суть и величина таких оптических эффектов была рассмотрена в монографии [3]. Действительно, хотя коэффициент экстинкции АМД при указанных длинах волн в несколько раз ниже, чем при 445 нм, но за счёт высокого внутриклеточного концентрирования АМД (клетки при оптическом микроскопировании в проходящем свете видны окрашенными в желтоватый цвет) локальные оптические плотности АМД при 295 ѐ 338 нм составляли в сумме около 0,2 . Это означает, что интенсивность триптофановой флуоресценции белков должна быть снижена примерно на половину, что и наблюдалось в опыте.

Таблица 2. Влияние внутриклеточного актиномицина Д на интенсивность триптофановой флуоресценции белков клеток HeLa.

\begin{tabular}{|c|c|}
\hline Cocras про6т & 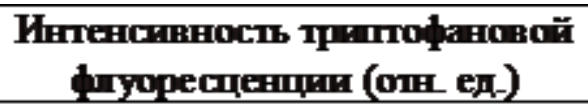 \\
\hline Kretza & $14 \pm 0,1$ \\
\hline Kmепқи с АMД & $7 \pm 0,1$ \\
\hline 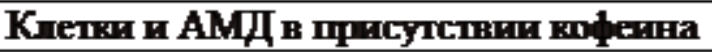 & $12 \pm 0,1$ \\
\hline
\end{tabular}

Примечание: Возбуждение - 295 нм, излучение - 338 нм. Концентрация АМД - 10 мкМ. 
Интересно, что добавление в среду кофеина в миллимолярной концентрации заметно снижало выше описанный эффект. По-видимому, избыточные кластеры кофеина в растворе сорбировали АМД на себя, не давая ему перераспределяться к внутриклеточной ДНК, т.е. избыток кофеиновых кластеров препятствует накоплению AMД в клеткаX HeLa. Это согласуется с данными, полученными ранее на дрожжевых клетках [1].

С помощью оптической микроскопии (для визуализации антибиотика в клетках) и цифровой фотосъемки с помощью фотокамеры было зарегистрировано, что АМД (или его комплекс с кофеином) при $20^{\circ} \mathrm{C}$ сорбируется на плазматической мембране клеток HeLa в течение первых 10 мин и затем постепенно медленно проникает внутрь клеток при комнатной температуре, в течение 30-минутной инкубации.

Фотодеструкиия антибиотика. АМД в комплексе с ДНК обладает фотодинамической активностью: в электронно-возбужденном состоянии акцептирует с ДНК электрон, что приводит к генерации свободных радикалов [1].

АМД обладает фотодинамической активностью также сам по себе, без ДНК. При облучении водного раствора АМД в зеркальной микрокювете светом 450-вт ксеноновой лампы (с использованием 5\%-го раствора сульфата меди в качестве теплового фильтра) обнаруживается фотохимическое превращение самого антибиотика, видное по фотообесцвечиванию выцветанию в спектре поглощения (рис. 1).

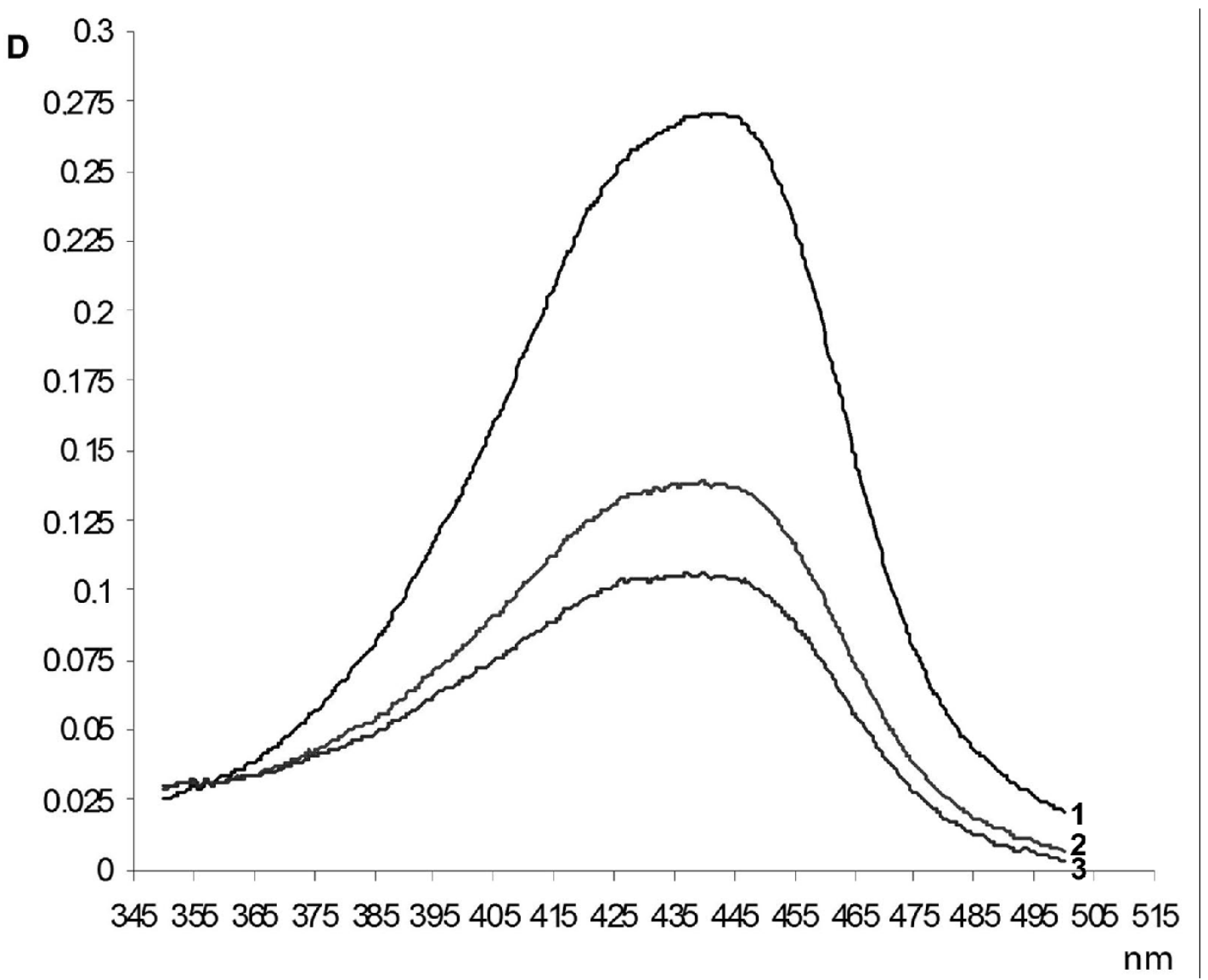

Рисунок 1.

Фотообесцвечивание АМД в водном растворе: спектр поглощения исходно (1), после облучения (2) и после облучения в присутствии кофеина (3). Спектры поглощения измерены сразу же после 18 минут облучения. 
Фотообесцвечивание осуществляется за счёт прямой фотохимической трансформации АМД и путём его фотоокисления молекулярным кислородом или синглетным кислородом, образующимся при взаимодействии с триплетным возбужденным АМД [1].

Как видно из рисунка 1, кофеин в миллимолярных концентрациях увеличивает степень фотообесцвечивания АМД. Вероятно, это связано с тем, что при сорбции на поверхности кофеиновых кластеров антибиотик существенно экранирован от воды, забирающей энергию электронного возбуждения на свои колебательные моды $[1,4]$.

В случае 7ААМД, при очень малых концентрациях антибиотика, выцветание наглядно проявляется в уменьшении интенсивности его флуоресценции. Например, при измерениях на флуоресцентном корреляционном микроскопе ConfoCor причиной этого был переход фотовозбужденных молекул 7ААМД в триплеты - из-за высокой плотности лазерного возбуждающего света [5]. При описании двух-экспоненциальных зависимостей были получены примерно равные компоненты с характерными временами в 2 и 34 с, т.е. 7ААМД в водном растворе существует в двух отличающихся по фотостабильности состояниях.

На рисунке 2 показано фотообесцвечивание 7ААМД в воде, измеренное на обычном спектрофлуориметре в зеркальной микрокювете. Такое флуоресцентное фотообесцвечивание вряд ли вызвано переходом в триплетное состояние, т.к. сохраняется в течение нескольких минут. После прерывания освещения и выдерживании пробы в темноте в течение 1 или 2 мин (на 20-21-й и на 30-32-й минутах) последующая интенсивность флуоресценции слегка повышается, но не возвращается к исходной.

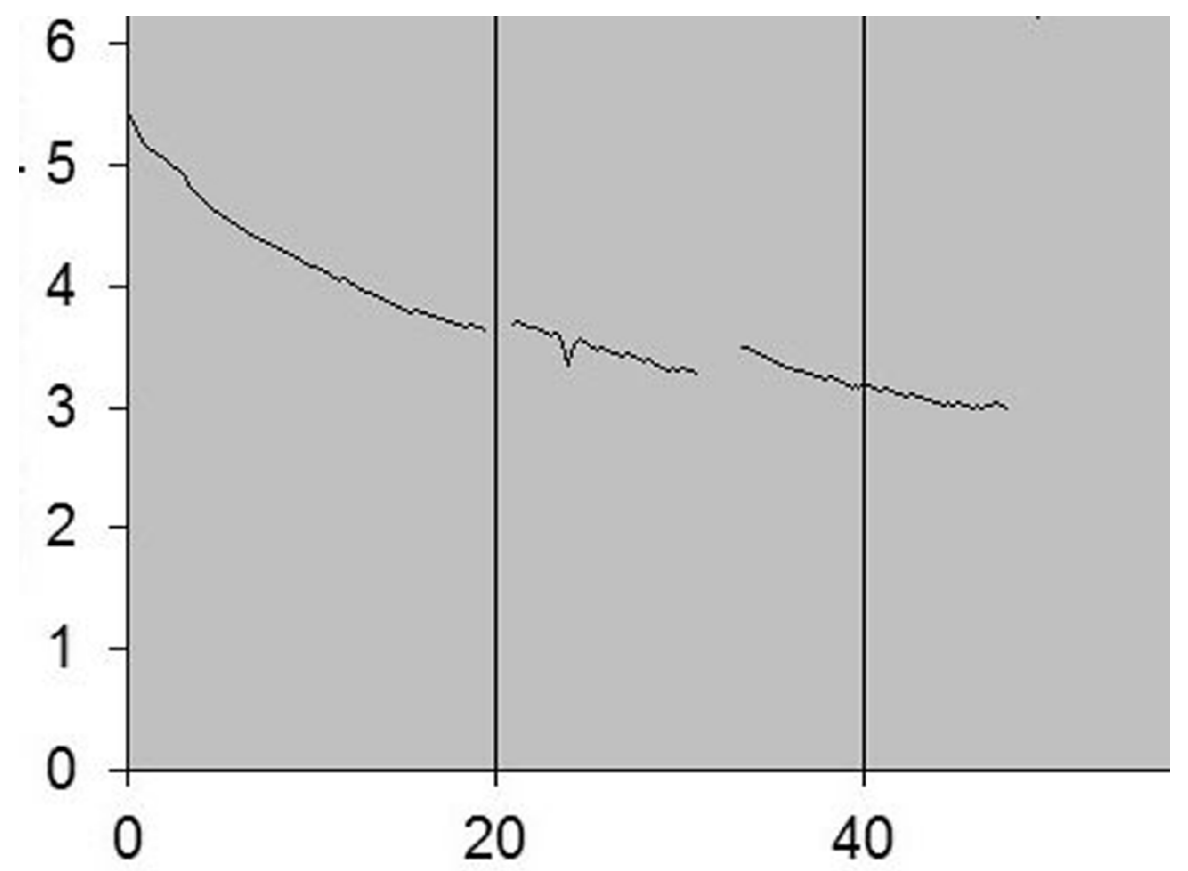

Рисунок 2.

время, мин.

Изменение интенсивности флуоресценции (отн. ед.) 7-ААМД в водном растворе под действием облучения 540 нм (освещаемый объем - 200 мкл, в зеркальной микрокювете).

Разрыв между 20-21-й и 30-32-й минутах - это выдерживание пробы в темноте, без освещения. Концентрация 7-ААМД - 5 мкМ. 
При связывании с ДНК фотохимическая активность 7ААМД способна повышаться, что может быть использовано в фотодинамической терапии. Наиболее фотохимически активным был комплекс с фрагментированной тимусной ДНК, а наименее фоточувствительным - с плазмидой pGEM3Zf(+) [5].

Интересно, что в случае с ДНК из фага лямбда (такая ДНК, в отличие от тимусной ДНК, практически не содержит разрывов и расплетённых участков) фотообесцвечивание 7ААМД, наоборот, заметно снижается (по сравнению с 7ААМД в воде). На рисунке 3 показано изменение интенсивности флуоресценции 7ААМД в присутствии лямбда-ДНК. Видно, что в первые несколько минут происходит заметное возрастание интенсивности, а после 5-й минуты - медленное снижение. Возрастание вызвано, по-видимому, повышением связывания дополнительных молекул антибиотика макромолекулой лямбда-ДНК в ходе облучения. После того, как процесс такого фото-индуцированного связывания в основном завершен, наблюдается медленное фотообесцвечивание. Не исключено, что после 5-й минуты имеет место наложение двух процессов: связывания и фотообесцвечивания.

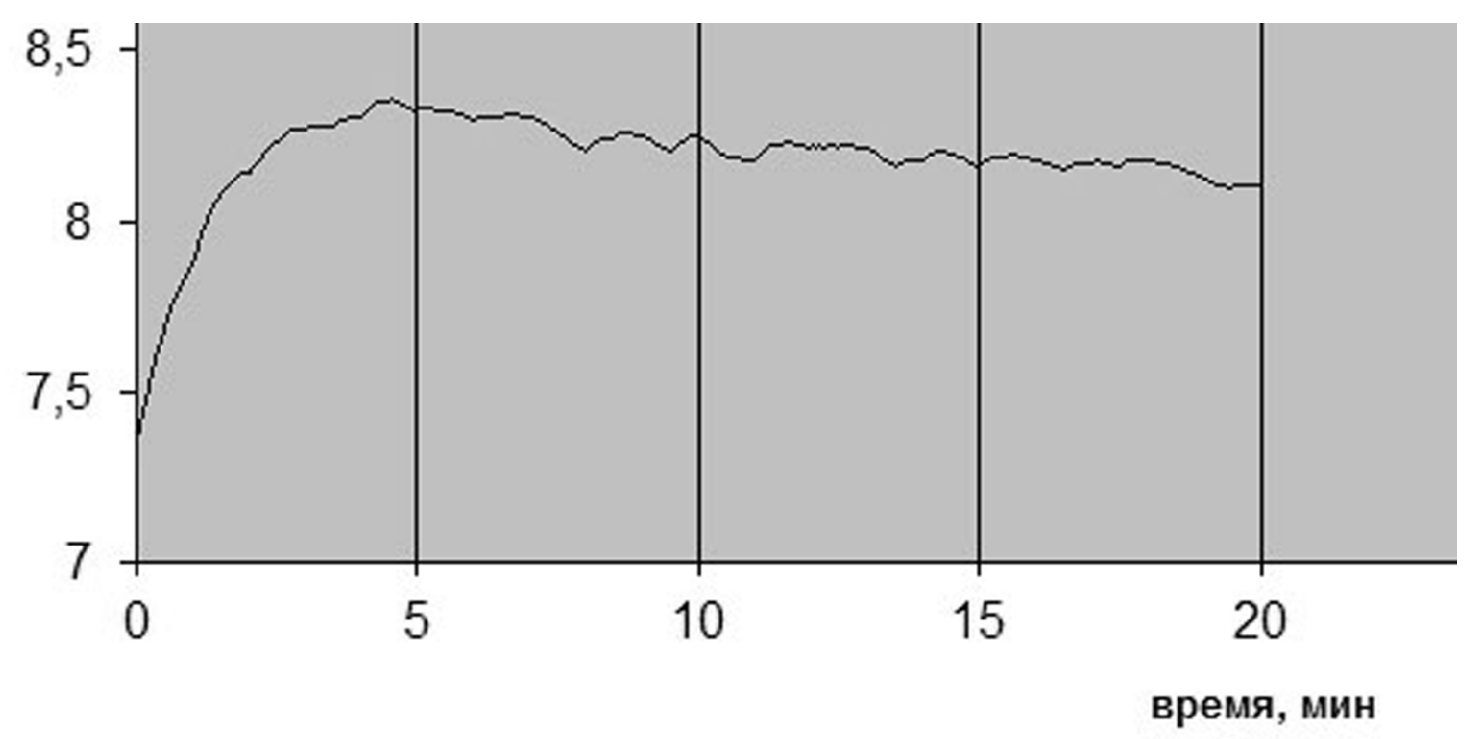

Рисунок 3.

Изменение интенсивности флуоресценции (отн.ед.) 7-ААМД в присутствии лямбда-ДНК под действием облучения 540 нм. Концентрация 7-ААМД - 5 мкМ, концентрация лямбда-ДНК - 50 мкМ (пар нуклеотидов).

Фотодеструкция опухолевых клеток. Оказалось, что АМД заметно способствует фотодеструкции клеток HeLa. Без антибиотика при облучении светом (450-вт ксеноновая лампа с тепловым фильтром) в течение 5 мин повреждается и разрушается всего около $20 \%$ клеток, а при проникновении АМД - около 60\% (табл. 3). Повреждение и разрушение клеток без антибиотика вызвано фотосенсибилизацией внутриклеточных хромофоров (флавопротеинов, цитохромов и др.). Клетки HeLa, прокрасившиеся антибиотиком, фотосенсибилизируются теми молекулами АМД, которые “налипли” снаружи, и теми, которые проникли внутрь. При этом клетки в большинстве своём полностью разрушаются, а не только повреждаются. 
Таблица 3. Гибель клеток HeLa при их фотосенсибилизации.

\begin{tabular}{|c|c|c|c|}
\hline Cocras про6̆ & 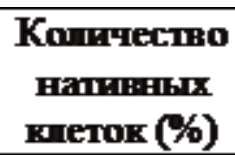 & $\begin{array}{c}\text { Коптество } \\
\text { потредденін } \\
\text { кшеток (\%) }\end{array}$ & 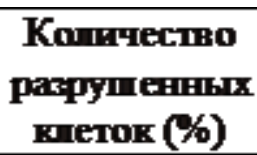 \\
\hline Kmenki & $100 \pm 1$ & $\mathbf{0} \pm 1$ & $\mathbf{0} \pm 1$ \\
\hline 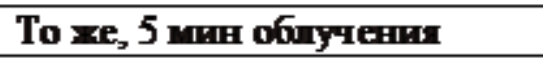 & $80 \pm 1$ & $12 \pm 1$ & $8 \pm 1$ \\
\hline 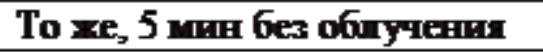 & $99 \pm 1$ & $1 \pm 1$ & $\mathbf{0} \pm \mathbf{1}$ \\
\hline 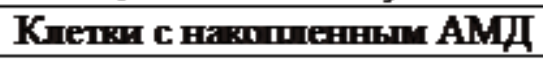 & $100 \pm 1$ & $\mathbf{0} \pm \mathbf{1}$ & $\mathbf{0} \pm 1$ \\
\hline 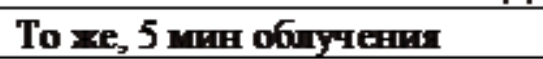 & $40 \pm 2$ & $15 \pm 2$ & $45 \pm 2$ \\
\hline To xe, 5 min 6es ofry yenam & $98 \pm 1$ & $2 \pm 1$ & $\mathbf{0} \pm \mathbf{1}$ \\
\hline
\end{tabular}

Примечание: Концентрация AMД - 10 мкM. Микрофотографии клеток HeLa, были получены с помощью микроскопа Carl Zeiss и цифровой фотокамеры Sony Cyber Shot (5 Мегапикселей).

При фотодеструкции клеток HeLa антибиотик, связанный с ДНК, вместе с ней попадает в раствор. При этом оптическая плотность повышается (табл. 4). Это однозначно говорит о том, что светопоглощательная способность АМД внутри клеток существенно ниже, чем в растворе. Такой факт позволяет предположить, что в случае 7-ААМД (табл. 1) первоначально низкая интенсивность его флуоресценции в клетках была вызвана той же причиной низким светопоглощением (а не тушением).

Таблица 4. Параметры спектра поглощения актиномицина Д при фоторазрушении клеток HeLa.

\begin{tabular}{|c|c|c|c|}
\hline Cocras пробы & $\begin{array}{c}\text { Masminym } \\
\text { crexpa } \\
\text { normonemat } \\
\text { (Him) }\end{array}$ & 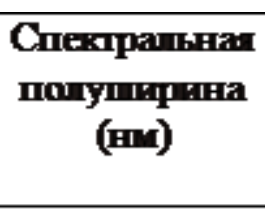 & $\begin{array}{l}\text { Omm4eckat } \\
\text { Imonhocm } \\
\text { B masmingme }\end{array}$ \\
\hline 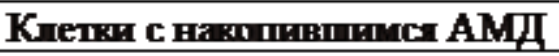 & 450 & $90 \pm 2$ & $0,105 \pm 0,01$ \\
\hline To ze, nocre 5 mint ofly yеная & 445 & $102 \pm 2$ & $0,134 \pm 0,01$ \\
\hline
\end{tabular}

Примечание: Концентрация АМД - 10 мкМ. Фотодеструкция проводилась в течение 5 минут с помощью 450-вт ксеноновой лампы через тепловой фильтр (5\% раствор сульфата меди). Образцы при облучении и последующем спектрофотометрировании находились в стандартных 1-см кварцевых кюветах.

Коротковолновый сдвиг максимума поглощения АМД после фотодеструкции клеток HeLa составлял 5 нм. Так как АМД довольно гидрофобен, то, по-видимому, спектр АМД, регистрируемый после фотодеструкции клеток, обусловлен в основном не свободными молекулами антибиотика, а связанными с ДНК (т.к. с белками антибиотик вообще не связывается).

Интересно, что полуширина спектра АМД в клетках заметно выше, чем в чистом водном растворе (около 70 и 100 нм, соответственно), причём, и исходно, и особенно после облучения. По-видимому, это вызвано гетерогенным взаимодействием АМД с плазматической мембраной клетки, с ядерной ДНК и с другими внутриклеточными структурами.

Можно предложить несколько механизмов наблюдаемой фотодеструкция клеток HeLa. Bo-первых, фотодеструкция может осуществляться за счёт 
сильного внутриклеточного неравновесного теплового нагрева, возникающего при поглощении квантов света молекулами АМД, накопившимися внутри клеток. Каждый световой квант обладает большой энергией. К примеру, квант с длиной волны 450 нм при поглощении молекулой АМД будет трансформироваться в колебательную тепловую энергию 63 ккал/моль. Во-вторых, фотодеструкция может происходить путем фотохимических реакций фотовозбужденных (триплетных) молекул антибиотика с клеточными мембранами, органеллами и ДНК. В-третьих, нельзя исключить роль перекисного окисления мембранных липидов, индуцируемого синглетным кислородом (генерируемым триплетным АМД).

Кофеин и актиномициновые фармакосомы. Кластеры кофеина при миллимолярных концентрациях в воде формируются спонтанно. Каждый кластер состоит из 8-12 молекул [4]. При добавлении АМД или 7ААМД к кофеиновым кластерам они сорбируются на их поверхности. Эквимолярный комплекс АМД с кофеином (здесь кофеин - в микромолярной концентрации, a не в миллимолярной) довольно легко проникает в делящиеся клетки (а сам АМД проникает хуже) [1]. Поэтому блокирующее действие таких комплексов на опухолевые клетки хорошо выражено. Причём, перераспределение антибиотика к ДНК в ходе диссоциации комплексов АМД/кофеин обусловлено как большей прочностью комплексов АМД/ДНК, так и наличием в ДНК большого количества мест связывания $[4,6]$.

Известно, что кофеин уменьшает опасное действие многих гетероциклических канцерогенов, в частности - бромида этидия (вероятно за счёт образования между ними прочного интеркаляционного комплекса [1]). Хотя кофеин, вообще говоря, может снижать действие гетероциклических противоопухолевых препаратов, сорбируя их на себе и этим уменьшая их эффективную концентрацию в крови, однако, при этом он препятствует "размазыванию" лекарства по стенкам кровеносных сосудов и капилляров, а также существенно пролонгирует время действия. Во многих случаях важна не столько концентрация лекарственного вещества в крови как таковая, сколько его способность проникать к молекулярно-биологическим “мишеням" в раковых клетках.

При введении комплексов, состоящих из АМД, кофеина и олигонуклеотида НР1, мышам с саркомой продолжительность жизни животных увеличивалась вдвое $[1,2]$, в то время как введение антибиотика отдельно увеличивало срок жизни всего на 1-2 дня, а введение одного олигонуклеотида или кофеина вообще не влияло.

Для доставки гетероциклических антибиотиков, в частности актиномицинов, к ДНК раковых клеток был предложен способ [7] с использованием фармакосом - частиц диаметром 1-10 нанометров, состоящих из антибиотика, одноцепочечного шпилечного олигонуклеотида и кластера кофеина. В фармакосомах обеспечивается защита антибиотика от сорбции на стенках кровеносных капилляров и при этом, что очень важно, увеличивается его проникновение в опухолевые клетки. Этот подход, в принципе, может быть использован при лечении сарком, лимфом, меланом и т.п. Одиночные не слипающиеся фармакосомы способны легко проходить по кровеносным капиллярам, доставлять антибиотик к ДНК делящихся опухолевых клеток и успешно проникать через их плазматическую и ядерную мембраны. Использование данного способа позволит во много раз снизить лечебную концентрацию антибиотика. 


\begin{abstract}
Автор выражает признательность студентам Андрею Кучину, Михаилу Бычкову, Надежде Ещенко и Яне Ким за активное участие в предварительных опытах. Работа поддержана грантом “Фундаментальные науки - медицине”.
\end{abstract}

\title{
ЛИТЕРАТУРА
}

1. Векшин Н.Л. (2009) Биофизика ДНК-актиномициновых нано-комплексов, Фотон-век, Пущино.

2. Векшин Н.Л., Савинцев И.В. (2009) Биофизика, 54(6), 1037-1041.

3. Векшин Н.Л. (2008) Флуоресцентная спектроскопия биополимеров, Фотон-век, Пущино.

4. Битехтина М.А., Векиин Н.Л. (2008) Биоорг. химия, 34(2), 256-261.

5. Ковалев А.Э., Яковенко А.А., Векшин Н.Л. (2004) Биофизика, 49 (6), 1030-1037.

6. Vekshin N., Kovalev A. (2006) J. Biochem., 140, 185-191.

7. Векиин Н.Л. (2009) Патент РФ № 2372073, Доставка гетероциклических антибиотиков к раковым клеткам с помощью нано-нуклеотидных фармакосом.

Поступила: 18. 05. 2012.

\section{PHOTO-ACTIVITY OF ACTINOMYCINS}

\author{
N.L. Vekshin \\ Institute of Cell Biophysics, Pushchino, Moscow region, 142290 Russia; \\ e-mail: nvekshin@rambler.ru
}

\begin{abstract}
Using actinomycins as an example, the possibility of increasing the anti-tumor activity of heterocyclic antibiotics due to photo-activation, has been studied. In model experiments with solutions of actinomycins, it was showed that actinomycins have a significant photochemical activity (of its own), changing by the binding to DNA in solution or in tumor cells. Photo-destruction of HeLa cells and the release of the antibiotic were observed.
\end{abstract}

Key words: anti-cancer antibiotics, actinomycin, 7-amino-actinomycin D, fluorescence, HeLa cells, photo-destruction, caffeine. 